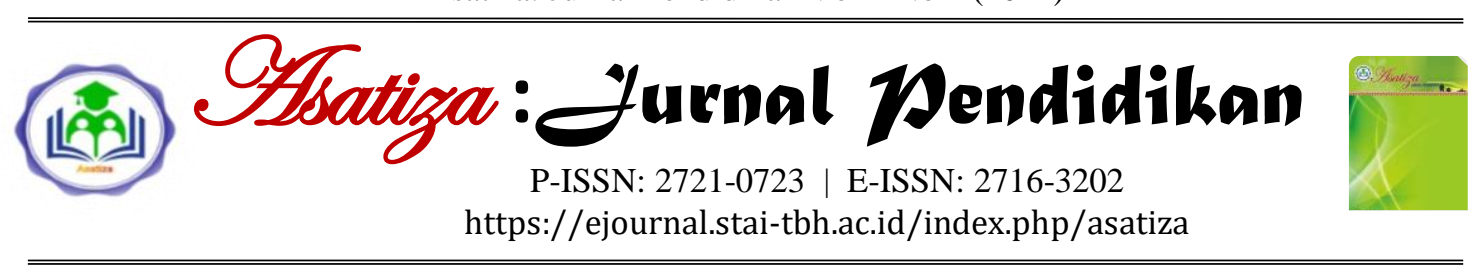

\title{
Manajemen Pendidikan, Tenaga Kependidikan, Standar Pendidik, dan Mutu Pendidikan \\ Heri Susanti ${ }^{1 *}$ \\ ${ }^{1}$ Madrasah Aliyah Negeri 01, Indragiri Hilir, Riau. Indonesia
}

\begin{tabular}{|c|c|}
\hline $\begin{array}{l}\text { INFORM } \\
\text { ARTIKE } \\
\end{array}$ & \\
\hline Histori A & tikel: \\
\hline Diterima & $: 16 / 12 / 2020$ \\
\hline Direvisi & : 26/12/2020 \\
\hline Disetujui & $: 05 / 01 / 2021$ \\
\hline Diterbitka & $:$ : 18/01/2021 \\
\hline
\end{tabular}

\section{Keywords: \\ Education \\ management, teacher standards, education personnel, quality of education}

\section{Kata Kunci: \\ Manajemen pendidikan, standar pendidik, tenaga kependidikan, mutu pendidikan}

\begin{tabular}{l}
\hline DOI: \\
https://doi.org/10.46963/ \\
asatiza.v2i1.254 \\
\hline
\end{tabular}

*Correspondence

\section{Author:}

susantiamara@gmail.co $\underline{\mathrm{m}}$

\begin{abstract}
Globalization is a necessity, and its movement continues to grow and almost touches various aspects of human life, including education. However, the function of education as a part of the national character building must be maintained. Likewise, education management at the strategic, managerial, and operational levels determine the quality of education. Three aspects of educational management that are important are the issues of educational leadership, teacher standards, and education personnel which directly influence the quality of education. Predictably, effective educational leadership will support and realize the teacher standards and education personnel, which in turn will also improve the quality of education. This research focused on teachers' management, education personnel, teacher standards, and education quality. A qualitative descriptive approach was chosen as a design for this study.

Abstrak

Arus globalisasi adalah sebuah keniscayaan. Efek dari pertumbuhan dan perkembangan teknologi informatika, dan perkembangan ekonomi dunia, gerak globalisasi ini terus berkembang dan hampir menyentuh berbagai aspek kehidupan manusia, termasuk dalam dunia pendidikan. Meski demikian, fungsi pendidikan sebagai bagian pembangunan karakter bangsa (national character building) harus tetap dipertahankan. Begitu pula dengan Manajemen pendidikan dalam tataran strategis, manajerial, maupun operasional menentukan mutu pendidikan. Tiga aspek dalam kajian manajemen pendidikan yang penting adalah persoalan kepemimpinan pendidikan, standar pendidik dan tenaga kependidikan berbanding lurus dengan mutu pendidikan. Kepemimpinan pendidikan yang efektif diprediksi akan mampu menunjang bagi upaya merealisasikan standar pendidik dan tenaga kependidikan, yang selanjutnya tentu akan menunjang pula bagi upaya peningkatan mutu pendidikan. Kajian ini difokuskan pada manajemen tenaga pendidik, Tenaga kependidikan, Standar Pendidik, dan Mutu Pendidikan. Penelitian ini dilakukan dalam bentuk penelitian pustaka (library Research) dengan pendekatan Deskriptif Kualitatif.
\end{abstract}

Cara mensitasi artikel:

Susanti, H. (2021). Manajemen pendidikan, tenaga kependidikan, standar pendidik, dan mutu pendidikan. Asatiza: Jurnal Pendidikan, 2(1), 33-48. https://doi.org/10.46963/asatiza.v2i1.254

\section{PENDAHULUAN}

Bangsa Indonesia dewasa ini dihadapkan pada upaya peningkatan Sumber Daya Manusia (SDM). Hal ini diharapkan dapat menjadikan insan yang berpengetahuan dan berwawasan luas sehingga dapat bersaing dengan bangsa lain dengan kata lain, bahwa bangsa Indonesia mau tidak mau harus lebih memperhatikan bidang pendidikan sebagai sarana ke arah tersebut. Karena

Editorial Address: Kampus STAI Auliaurrasyidin Tembilahan 
mustahil Sumber Daya Manusia yang berkualitas dan pembangunan di segala bidang dapat dicapai tanpa melalui pendidikan. Mutu Pendidikan Nasional akan terukur lewat ketercapaian segenap Standar Pendidikan Nasional, meliputi standar isi, proses, kompetensi kelulusan, pendidik dan tenaga kependidikan, sarana dan prasarana, pengelolaan, pembiayaan dan penilaian pendidikan (PP RI No. 19 tahun 2005 telah disempurnakan dengan PP RI No. 32 tahun 2013). Perhatian yang serius dan sungguh-sungguh oleh para pihak terhadap upaya pemenuhan dan perwujudan segenap standar tersebut akan menentukan kualitas atau mutu pendidikan.

Persoalan mutu pendidikan merupakan isu yang selalu hangat dan menarik untuk diperbincangkan dan dikaji. Persoalan mutu pendidikan selaras dengan tuntutan perkembangan dan perubahan, menuntut peran agen pembaharuan (The agent of change) dalam memunculkan ide-ide pembaharuan serta mengelola perubahan. Sosok agen perubahan secara internal lembaga pendidikan dimaksud adalah adanya pemimpin yang menjalankan kepemimpinan secara efektif, yaitu kepemimpinan yang mampu memanajemen segenap sumber daya di lembaga yang dipimpinnya ke arah visi dan misi yang diharapkan. Terutama sumber daya manusia yaitu pendidik dan tenaga kependidikan yang disinyalir sarat dengan berbagai persoalan, diantaranya persoalan kualifikasi, pembinaan dan pengembangan keprofesionalan, serta kinerjanya yang sangat membutuhkan perhatian, arahan dan bimbingan yang intensif dan berkelanjutan sehingga betulbetul mampu menjalankan segenap tugas, fungsi dan tanggung jawabnya secara profesional, selaras dengan tuntutan standar pendidik dan tenaga pendidikan yang diprasyaratkan.

Menurut Mohd. Ansyar, ada tiga faktor penentu kualitas atau mutu pendidikan, yaitu:

"(a) orang (pendidik), (b) program (kurikulum) dan (c) institusi (pimpinan)". Dengan demikian upaya pemenuhan dan perwujudan segenap standar pendidikan nasional idealnya harus didukung oleh personal (orang) yang berkualitas, dibarengi dengan program (kurikulum) yang baik serta institusi (pimpinan) yang efektif.” (Ansyar, 2012)

Realitas di lapangan faktor yang sering disorot dan diperhatikan oleh pemerintah dan pemangku kebijakan adalah melakukan perubahan dari segi programnya (perubahan kurikulum) tanpa dibarengi dengan upaya yang selaras dan seimbang dengan upaya membenahi orangnya (tenaga pendidik dan kependidikan), demikian juga halnya dengan manajemen dan pengelolaan pendidikan (oleh pimpinan terhadap institusinya). Maksudnya program (kurikulum) berubah, namun orang yang akan menjalankannya serta manajemen terhadap implementasi program (kurikulum) tidak tertata dan terkelola dengan baik. Akhirnya program (kurikulum) yang ditetapkan tidak mampu diimplementasikan secara maksimal sesuai dengan yang diharapkan, karena tidak diiringi oleh kompetensi pendidik dan tenaga kependidikan yang memadai, serta tidak pula ditunjang oleh manajemen 
yang baik, seperti tidak adanya pengawasan atau kontrol yang intensif dan berkesinambungan terhadap upaya implementasi program (kurikulum) yang berkelanjutan (sustainability).

Permasalahan di atas dapat diidentifikasi dari munculnya berbagai komentar, keluhan dan kritikan dari para pendidik dan tenaga kependidikan dengan ungkapan "ganti pimpinan ganti kebijakan, ganti menteri ganti kurikulum". Hal ini merupakan indikasi bahwa perubahan (change) yang dilakukan dalam bidang pendidikan tidak didasari oleh pemahaman yang benar tentang makna perubahan. Padahal idealnya perubahan dilakukan harus melibatkan segenap unsur terkait dalam rangka mengidentifikasi input-input yang relevan dan berguna dalam pengambilan keputusan, sehingga keputusan atau kebijakan yang diambil dimengerti oleh pihak terkait hingga akhirnya mendapatkan dukungan dan dapat diimplementasikan dengan baik. Dengan kata lain tidak akan terjadi resistance to change, jika para pihak terkait merasa dilibatkan dan dihargai serta merasa menjadi bagian penting bagi upaya perwujudannya.

Kepemimpinan adalah salah satu faktor penentu keberhasilan dalam pencapaian standar mutu pendidik dan tenaga kependidikan guna peningkatan kualitas dan mutu pendidikan pada suatu lembaga pendidikan. Seorang pemimpin harus memiliki kemampuan manajerial yang baik, sehingga mampu membawa unsur-unsur lembaga secara sistematik ke arah yang diinginkan sesuai dengan visi, misi dan tujuan lembaga yang dipimpinnya. Pemimpin lembaga pendidikan harus mampu mewujudkan program yang berkelanjutan (sustainability) mengacu pada standar mutu yang dipersyaratkan.

Persoalan mutu pendidikan sebetulnya tidak dapat dikaji secara parsial, karena persoalan mutu pendidikan adalah persoalan yang sistematik. Namun pembahasan tentang mutu pendidikan kali ini dibatasi tentang persoalan kepemimpinan kaitannya dengan upaya merealisasikan standar pendidik dan tenaga kependidikan dalam rangka pencapaian standar mutu pendidikan atau dalam rangka meningkatkan mutu pendidikan di suatu lembaga pendidikan khususnya. Tulisan ini membahas beberapa persoalan relevan dan penting pada saat ini yaitu:

1. Memaparkan konsepsi dan implikasi kepemimpinan pendidikan, standar mutu pendidik dan tenaga kependidikan serta mutu pendidikan.

2. Membahas peran kepemimpinan dalam mewujudkan program dan mutu pendidikan yang berkelanjutan bagi pendidik dan tenaga kependidikan.

3. Mengemukakan tentang pentingnya komitmen kepemimpinan bagi upaya merealisasikan standar pendidik dan tenaga kependidikan dalam rangka peningkatan mutu pendidikan di suatu lembaga pendidikan.

\section{METODE}

Studi ini adalah studi kualitatif dengan pendekatan scientefic review. Di mana data-data disampaikan secara kualitatif dengan pendekatan studi literatur yang dihasilkan dari penelitian-penelitian yang telah dilakukan dan buku-buku ilmiah yang kemudian digunakan untuk 
menjawab permasalahan-permasalahan yang dikaji dalam studi ini. Sedangkan metode kualitatif adalah metode yang bertujuan untuk mendeskripsikan dan menganalisis fenomena, peristiwa, aktivitas sosial, sikap, kepercayaan, persepsi, dan pemikiran orang secara individu maupun kelompok (Sukmadinata, 2007).

\section{HASIL DAN PEMBAHASAN}

\section{A. Konsepsi dan Implikasi (Kepemimpinan, Standar Pendidik dan Tenaga Kependidikan, Mutu Pendidikan)}

Sejumlah keterampilan yang digunakan seseorang di dalam organisasi, dan kepemimpinan adalah kombinasi dari segala hal. Pemimpin perlu memiliki pandangan tentang masa depan dan membawa orang-orang yang dipimpinnya untuk mencapai tujuan orang yang dipimpinnya untuk mencapai tujuan yang diinginkan organisasi. (Rivai, 2004)

Menurut Bennis dan Nanas mengatakan, "Leadership is necessary to help organizations develop a new vision of what they can be, then mobilize the organization change toward the new vision." Definisi tersebut mengisyaratkan bahwa pemimpin harus mampu menjadi agen perubahan bagi lembaga yang dipimpinnya. Perubahan yang dimaksud adalah perubahan yang memiliki visi yang jelas. (Bennis, Warren, \& Nanas, 1985)

Menurut Sallis mengatakan
seorang pimpinan rapat
mengembangkan bawahan (orang

yang dipimpinnya) dengan mengupayakan berbagai segi, secara individual maupun kelompok, secara psikologis maupun sosiologis, secara implisit maupun eksplisit yang konkretnya dapat dirujuk pada rincian sikap dan perilaku atau aktivitas yang dikemukakan dirinci sebagai berikut: (1) menginisiasikan diskusi, mencari informasi dan opini, (3) mengusulkan prosedur untuk mencapai tujuan, (4) menjelaskan atau mengurai ide, (5) menyimpulkan, (6) tes untuk mufakat, (7) bertindak sebagai moderator, (8) kompromis dan kreatif dalam mengatasi perbedaan, (9) mencoba mengurangi ketegangan dalam kelompok dan berupaya menembus masalah-masalah yang sulit. (10) mengekspresikan perasaan kelompok dan meminta yang lain untuk mengecek kesan tersebut, (11) membuat kelompok setuju terhadap standar, (12) merujuk pada dokumen dan data (13) memuji dan mengoreksi anggota dengan cara yang adil, dan mampu menerima komplain sama baiknya dengan pujian. (Sallis, 1993 )

Belasco dalam Abdul Aziz Wahab mengemukakan hambatanhambatan potensial yang harus diwaspadai, dipahami dan diantisipasi seorang pemimpin demi keterlaksanaan perubahan (memberdayakan kinerja) yaitu: (Wahab, 2008).

Pertama, It always take longe. Orang lamban belajar dan dapat melupakan masalahnya dengan mudah, dan biasanya berlangsung lama dari yang diharapkan. Mengubah 
kebiasaan-kebiasaan yang berlangsung lama adalah sulit. Semakin besar organisasi maka akan semakin lama waktu yang dibutuhkan untuk berubah.

Kedua, Exagerated expectation, everyone wants everything nom. Jika orang didorong untuk siap maka mereka akan siap. Namun kadang mereka melihat itu suatu hal yang dapat dilakukan dengan instan. Untuk itu perlu orang yang dapat dipercaya untuk mengatasi berbagai masalah dalam berbagai situasi.

Ketiga, Carping sceptics. Dalam setiap organisasi profesional selalu saja ada orang yang bersikap skeptis. Bisa saja hal yang dimunculkan benar atau salah, karena itu setiap kritik yang muncul perlu diuji keseriusan dan keluasannya.

Keempat, Procastination. Perberda- an visi membutuhkan waktu yang tidak sedikit. Visi organisasi menghadapi berbagai hal yang tidak nampak seperti sikap pelanggan atau motivasi pegawai. Umumnya manajer menghindari hal-hal yang sulit diukur dan lebih sulit lagi untuk mempertahankan penilaian yang bersifat subjektif berhadapan dengan tantangan

Kelima, Imperfection. Harus siap dengan segala kekeliruan. Ubah kesalahan dan kekeliruan menjadi pengalaman belajar. Jadikan kesalahan menjadi kesempatan untuk refokus terhadap visi dan perjelas kembali peran setiap orang untuk membuat visi hidup. Agar perubahan dapat terlaksana dengan baik, maka pemberdayaan perubahan harus memperhatikan berbagai komponen yang relevan dengan perubahan yang dikehendaki.

Lebih lanjut Belasco dalam (Wahab, 2008) menjelaskan tentang pemberdayaan perubahan: Empowering change. "your actions tell the tell". Tindakan anda memberitahukan apa yang harus anda lakukan. Dasar setiap upaya perubahan adalah dedikasi dan komitmen yang ditunjukkan dalam tindakan konkrit, spesifik dan individual mendorong proses. Artinya tindakan yang mencerminkan visi akan memotivasi pekerja untuk menggunakan visi tersebut. (2) Getting ready to change. Perubahan dapat menyenangkan dan berhasil atau sebaliknya gagal. Orang bertahan dan bersikeras pada kebiasaan dan perilaku lama yang di masa lalu terbukti sangat berguna. Sadari hal ini akan membatasi kemajuan organisasi. (3) Anticipate the obstacles. Pemberdayaan perubahan tidak mudah dilakukan tapi mungkin dan sangat esensial untuk organisasi maju dan berkembang. Setiap hambatan dan masalah harus dihadapi dan diantisipasi. (4) Create tomorrow. Berbagai kondisi yang menyebabkan berbagai masalah harus dipecahkan. Anda harus dapat menentukan apa yang harus dilakukan dan akan ke mana organisasi di masa depan (tujuan). (5) Focus resources. Seorang eksekutif tanpa sumber daya ibarat kapal tanpa layar tidak akan dapat pergi kemanapun. Artinya perlu 
kejelasan fokus berawal dari strategi mengidentifikasi kegiatan makro yang esensial untuk dipertahankan dan menghilangkan yang tidak esensial. Demikian juga dengan aktivitasaktivitas mikro.

Fasli Jalal dan Dedi Supriyadi mengutip laporan Bank Dunia yang bertajuk Education in Indonesia: From Crisis to Recovery tanggal 23 September 1998 antara lain menyorot persoalan guru dan tenaga kependidikan, bahwa guru merupakan sentral dari upaya peningkatan mutu pendidikan, karena itu setiap upaya untuk membenahi pendidikan akan dan harus memelihara penataan terhadap guru. (Jalal \& Supriadi, 2001)

Tenaga pendidik atau guru yang profesional yaitu ia ahli dalam bidang yang diajarkannya, memiliki rasa tanggung jawab yang tinggi, memiliki rasa kesejawatan dan kode etik serta memandang tugasnya sebagai suatu karier hidup (Sahertian, 2000). Pada prinsipnya ada tiga isu dominan tentang guru yang disorot dalam laporan tersebut, yaitu "mutu guru yang berkaitan dengan pendidikan prajabatan dan seleksi, insentif yang diperolehnya, dan penyebaran guru yang tidak merata. Tantangan dan strategi ke depan adalah bagaimana meningkatkan mutu guru (melalui pendidikan prajabatan atau pendidikan dalam jabatan), membuat mereka lebih terlatih, tingkat kesejahteraan/insentif guru lebih baik, sehingga membuat profesi keguruan lebih menarik dan kompetitif, dan penyebaran guru lebih merata.
Pada umumnya tugas seorang pendidik membutuhkan landasan mental spiritual dan tanggung jawab dalam mengelola lembaga pendidikan, maka Allah memberi petunjuk kepada manusia bahwa seorang pendidik mempunyai kemampuan untuk menunjukkan orang lain ke jalan yang lurus. Sebagaimana firman-Nya dalam surah As-Syura ayat 52, yang berbunyi:
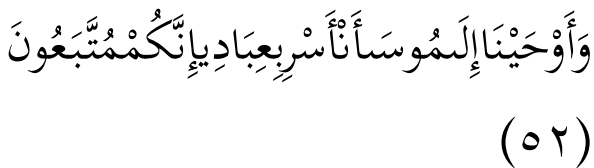

Artinya: Dan Kami wahyukan (perintahkan) kepada Musa: "Pergilah di malam hari dengan membawa hamba-hamba-Ku (Bani Israil), karena Sesungguhnya kamu sekalian akan disusuli".

Dengan petunjuk Allah dalam firman-Nya tersebut di atas itulah pelaksanaan manajemen diperlukan dalam mengembangkan akhlakul karimah dan upaya untuk meningkatkan ilmu pengetahuan tentang kehidupan dunia dan akhirat yang sesuai dengan nilai-nilai ajaran agama di dalam setiap kehidupannya.

Upaya pemenuhan harapanharapan tersebut secara politis sudah diatur dalam peraturan perundangundangan yaitu PP No 19 tahun 2005. Ada beberapa istilah dan penjelasan penting yang dapat disarikan tentang standar pendidik dan tenaga kependidikan yang terdapat dalam PP No 19 Tahun 2005 sebagai berikut: Pada pasal 1 dijelaskan bahwa: "Standar pendidik dan tenaga 
kependidikan adalah kriteria pendidikan prajabatan dan kelayakan fisik maupun mental, serta pendidikan dalam jabatan." Artinya standar itu meliputi sejumlah kriteria yang harus dipenuhi sebelum dan setelah menjalani jabatan sebagai pendidik dan tenaga kependidikan.

Secara garis besar ada dua kualifikasi yang dipersyaratkan yaitu kualifikasi akademik dan non akademik. Sebagaimana ditegaskan dalam pasal 28 bahwa pendidik dan tenaga kependidikan harus memiliki kualifikasi akademik dan kompetensi sebagai agen pembelajaran, sehat jasmani dan rohani, serta memiliki kemampuan untuk mewujudkan tujuan pendidikan nasional. Kualifikasi akademik yang dimaksudkan adalah tingkat pendidikan minimal yang harus dipenuhi oleh seorang pendidik dan tenaga kependidikan yang dibuktikan dengan ijazah dan/atau sertifikat keahlian yang relevan sesuai ketentuan perundang-undangan yang berlaku. Kompetensi sebagai agen pembelajaran pada jenjang pendidikan dasar dan menengah serta pendidikan anak usia dini meliputi: Kompetensi Pedagogik, Kompetensi Kepribadian, Kompetensi Profesional, dan Kompetensi Sosial. Kemudian bagi seseorang yang tidak memiliki ijazah dan/atau sertifikat keahlian tetapi memiliki keahlian khusus yang diakui dan diperlukan dapat diangkat menjadi pendidik setelah melewati uji kelayakan dan kesetaraan.

Kompetensi akademik dan kompetensi sebagai agen pembelajaran dikembangkan oleh BSNP (Badan Standar Nasional Pendidikan) dan ditetapkan dengan Peraturan Menteri. Kemudian dalam rangka mengupayakan guru yang memiliki kualifikasi akademik dan kompetensi telah dibentuk Lembaga Penjaminan Mutu Pendidikan yang selanjutnya disebut LPMP adalah unit pelaksana teknis Departemen yang berkedudukan di provinsi dan bertugas untuk membantu Pemerintah Daerah dalam bentuk supervisi, bimbingan, arahan, saran, dan bantuan teknis kepada satuan pendidikan dasar dan menengah serta pendidikan nonformal, dalam berbagai upaya penjaminan mutu satuan pendidikan untuk mencapai standar nasional pendidikan (pasal 1).

Kemudian pada pasal 2 dikemukakan bahwa untuk penjaminan dan pengendalian mutu pendidikan sesuai dengan Standar Nasional Pendidikan dilakukan evaluasi, akreditasi, dan sertifikasi.

Istilah mutu pendidikan mengacu pada konsep yang dikemukakan oleh (Sallis, 1993 ) bahwa "TQM is how much its philosophy corresponds with the best educational management practice." Dapat dipahami bahwa secara filosofis menekankan pada upaya praktik manajemen pendidikan terbaik. Selanjutnya dijelaskannya bahwa "TQM is a means of assuring quality and standards in education. It provides a philosophy as well as a set of tools for improving quality" Mutu pendidikan yang dimaksud adalah 
mutu yang berkelanjutan mengacu pada standar mutu pendidikan sesuai dengan tuntutan perkembangan dan kemajuan zaman yang berdasar.

Secara konseptual Sallis menegaskan bahwa konsep mutu merupakan suatu gagasan yang dinamis mengandung dua macam konsep yaitu konsep absolut dan konsep relatif (Sallis, 1993 ). Dalam bidang pendidikan konsep mutu absolut secara mendasar menciptakan kelompok elite. Konsep kualitas absolut mengandung "luxury and status". Secara keseluruhan konsep ini menampilkan standar yang tinggi. Secara konsep relatif (Sallis, 1993 ), mutu tidak dipandang sebagai atribut produk atau servis melainkan sebagai sesuatu yang dimiliki, yang tidak harus mahal dan eksklusif, tidak harus istimewa, bahkan mungkin biasa-biasa saja. Menurut konsep ini mutu ada saat kapan dibutuhkan artinya mutu harus sesuai dengan tujuan-tujuan yang diinginkan. Konsep mutu relatif mengandung dua aspek, yaitu (1) menggambarkan spesifikasi yang jelas, (2) memenuhi kebutuhan pelanggan. Mutu didemonstrasikan sebagai suatu prosedur dalam suatu sistem yang dipahami sebagai jaminan kualitas sistem, sehingga mampu memberikan layanan dan hasil yang baik bagi spesifikasi standar tertentu.

Mutu pendidikan selalu dihubungkan dengan biaya yang mahal. Akibatnya hanya segelintir orang yang mampu. Menarik sekiranya ada pakar yang mampu menawarkan biaya yang relatif rendah namun mampu memberikan mutu layanan dan kualitas sistem lembaga yang menjamin kepuasan pelanggan. Penulis optimis bahwa kepemimpinan yang efektif dan bijaksana dapat membawa ke arah mutu yang berkelanjutan dan terjangkau.

Sa'ud dalam makalahnya tentang penjaminan mutu, mengemukakan bahwa perbaikan mutu pendidikan secara berkelanjutan (continous quality improvement) perlu dilakukan dalam kerangka mutu, baik inisiatif sendiri (internal driven) dan atau melibatkan pihak eksternal. Pendekatan penjaminan mutu itu penting agar pendidikan dapat mengelola sumber daya secara optimal untuk menjamin mutu layanan akademik dan akuntabilitas pendidikan bagi stakeholders. (Sa'ud \& U, 2006)

Untuk mencapai target mutu dan standar mutu pendidikan yang diharapkan dibutuhkan tim yang tangguh yang terdiri dari segenap unsur tenaga pendidikaan dan non kependidikan. Mengapa tim yang tangguh penting? (Sallis, 1993 ) menjelas kan sebagai berikut:

1. Tim yang tangguh penting bagi sebuah organisasi (institusi) sebagai langkah awal atau pondasi yang kuat untuk membangun Total Quality Management (TQM). Dalam beberapa sektor pendidikan, tim telah dikembangkan sebagai unit dasar penyampaian kurikulum. 
2. Tim berfungsi menjalankan tugas tertentu dalam rangka fungsionalisasi kerja tim.

3. Berguna untuk mencapai proyek yang spesifik. (Proyek ad-hoc dan berjangka pendek serta tim peningkatan merupakan elemen kunci dalam meningkatkan mutu.)

4. Tim menjadi motor peningkatan mutu.

5. Tim memiliki sejumlah fungsi penting. Seperti dicontohkan oleh Miller, Dower \& Innis dalam (Sallis, 1993 ): pada tim penyusun mata pelajaran memiliki sejumlah fungsi penting: (1) bertanggung jawab pada mutu pembelajaran, (2) Bertanggung jawab pada pemanfaatan waktu para guru, material serta ruang yang dimanfaatkan, (3) menjadi sarana untuk mengawasi, mengevaluasi dan meningkatkan mutu, mengevaluasi dan meningkatkan mutu, (4) bertindak sebagai penyalur informasi kepada pihak manajemen tentang perubahanperubahan yang diperlukan dalam proses peningkatan mutu. "The team is a powerful means of making and proposing changes"

6. Tim adalah sebuah cara yang solid dalam membuat perubahan.

B. Implikasi Kepemimpinan Terhadap Upaya Merealisasikan Standar Pendidik dan Tenaga Kependidikan Bagi Pencapaian Mutu Pendidikan

Kepemimpinan yang dimaksud adalah kepemimpinan yang diterapkan oleh pemimpin pendidikan. (Lestari, 2011) mengutip beberapa pendapat pakar tentang pemimpin pendidikan kaitannya dengan efektivitas lembaga pendidikan (sekolah). Bush \& Coleman menyatakan bahwa pemimpin pendidikan adalah "Culture Creator". Menurut Duignan \& Macpherson bahwa efektivitas sekolah menekankan pentingnya apa yang terjadi di dalam kelas dan kepemimpinan pendidikan yang menyediakan suatu kultur di dalam proses belajar mengajar, oleh karenanya, pemimpin pendidikan memiliki tanggung jawab untuk menciptakan kultur organisasi yang mempertinggi pengembangan dan pertumbuhan organisasi. Kualitas yang diidentifikasi oleh Duignan dan Macpherson pada pemimpin pendidikan (educative leader), serupa dengan pemimpin transformational, yang menekankan pada pemimpin yang mendorong dan memberdayakan tanggung jawab bawahan dengan, menciptakan peluang untuk peserta (partisipan) dalam proses perubahan untuk merefleksikan praktik mereka dan mengembangkan pemahaman pribadi menyangkut implikasi dan perubahan diri mereka;

1. Mendorong mereka yang terlibat dalam implementasi suatu peningkatan untuk membentuk kelompok sosial dan menyediakan dukungan timbal balik sepanjang proses perubahan;

2. Menyediakan peluang umpan balik positif untuk semua yang terlibat dalam perubahan; dan

3. Sensitif pada hasil pengembangan proses dan menyediakan kondisi- 
kondisi penting bagi umpan balik dan tindak lanjut sehingga yang terlibat memiliki kesempatan mendiskusikan dan memikirkan kembali gagasan dan praktik mereka.

Fiedler dikutip Sulastri mencatat implikasi di atas untuk kepemimpinan pengajaran mencakup: (1) Mengelola pengajaran dan kurikulum; Pengawasan pengajaran;

Monitoring kemajuan siswa; dan (4) Menyediakan iklim mengajar yang mengajar. Northfield menambahkan bahwa kunci corak pemimpin mendidik (educative leader) adalah pemimpin menyediakan peluang untuk peserta mengembangkan pemahaman pribadi dan mendorong pada kondisikondisi untuk merefleksikan dalam praktik (Lestari, 2011).

Menurut Lunenberg \& Orstein secara garis besar pemimpin pendidikan memiliki tiga peran utama: bidang kepemimpinan, manajerial, dan kurikulum- pengajaran. Berikut akan dijelaskan masing- masing peran tersebut.

1. Peran kepemimpinan kepala sekolah

a. Kepala sekolah merupakan kunci dalam membentuk kultur sekolah. Kepala sekolah harus dapat membentuk budaya positif, di mana staf berbagi pengertian, dan memiliki dedikasi untuk peningkatan sekolah dan pengajaran. Sukses siswa disoroti dan kolegialitas menyebar keseluruh bagian sekolah. Moril tinggi, kepedulian, dan memiliki komitmen.

b. Kepala sekolah harus dapat menjalin hubungan dengan kelompok, internal dan eksternal sekolah, seperti (1) pengawas dan pengelola pendidikan pusat, (2) dewan sekolah, (3) teman sejawat, (4) orang tua, (5) masyarakat sekitar, (6) guru, (7) siswa, dan (8) kelompok eksternal seperti profesor, konsultan, badan akreditasi, dan sebagainya. Kepala sekolah yang efektif perlu untuk percaya pada kemampuan diri dan mampu menyinergikan persepsi, harapan, maupun kemampuan berbagai kelompok tersebut dapat memberi dukungan terhadap kemajuan sekolah.

2. Peran manajerial kepala sekolah

a. Peran manajerial merupakan aspek utama kepemimpinan sekolah. Katz dan Kanz membagi keterampilan manajemen ke dalam tiga area utama: (1) teknis (technical), mencakup teknik proses manajemen (peren- canaan, pengaturan, koordinasi, pengawasan, dan pengendalian), (2) manusia (human), keteram- pilan hubungan antar manusia, memotivasi dan membangun moral, (3) konseptual (conceptual), menekankan pengetahuan dan teknis terkait 
jasa (atau produk) tentang organisasi. Sergiovanni menambahkan dua area lain manajemen untuk pengurus sekolah, yaitu kepemimpinan simbolis (sym- bolic leadership), tindakan kepala sekolah memberi teladan (model) kepada warga sekolah, dan kepemimpinan budaya (cultural leadership), bahwa kepercayaan dan nilai-nilai kepala sekolah merupakan unsur penting. Fullan dan Sarason menambahkan suatu dimensi manajemen sekolah yaitu kepala sekolah sebagai agen perubahan (change agent) dan fasilitator.

b. Secara umum, kepala sekolah harus "memimpin dari pusat" (lead from the centre): demokratis, mendelegasikan tanggung-jawab, memberi kuasa dalam pengambilan keputusan, dan mengembangkan usaha kolaboratif yang mengikat siswa, guru, dan orang tua. Hal tersebut mengandung arti bahwa pemimpin dalam segala hal hendaknya ada di tengah komponen organisasi (partisipatif).

c. Lipham mengembangkan sebuah "teori empat faktor " (four-factor theory) tentang kepemimpinan untuk kepala sekolah, yaitu kepemimpinan struktural, (2) kepemimpinan fasilitatif, (3) kepemimpinan yang mendukung, dan (4) kepemimpinan partisipatif. Semua faktor kepemimpinan tersebut menekan kan ketrampilan manajerial dan administratif. Keberhasilan kepala sekolah adalah dapat memodifikasi atau menyesuaikan empat faktor kepemimpinan sesuai kebutuhan sekolah.

3. Peran kurikulum-pengajaran kepala sekolah bidang kurikulumpengajaran hendaknya menjadi prioritas kerja utama kepala sekolah sehingga dapat meningkatkan mutu pendidikan di sekolahnya. Murphy mengembangkan enam peran kepala sekolah dibidang kurikulum dan pengajaran, yaitu: menjamin kualitas pengajaran, (2) mengawasi dan mengevaluasi pengajaran, (3) mengalokasi dan melindungi waktu pengajaran, (4) mengkoordinir kurikulum, memastikan isi mata pelajaran tersampaikan, dan (6) monitoring kemajuan siswa. Menurut Murphy, enam peran tersebut menggambarkan suatu contoh kepala sekolah efektif.

C. Peran Kepemimpinan dalam Mewujudkan Program dan Mutu Pendidikan yang Berkelanjutan Waddel dkk. (2004) sebagaimana yang dikutip dalam Hidayati (2015, hlm. 58) mengemukakan bahwa untuk tujuan "sustainability", (keberlanjutan) suatu program butuh kemampuan untuk 
mengimplementasikan peningkatan dan transformasi perubahan. Serta menuntut keterampilan organisasional dan manajemen secara bersamaan dalam suatu kematangan pasar di mana biaya, efisiensi, dan peningkatan inovasi menjadi kunci. Kemudian untuk mengembangkan produk baru dan layanan di mana inovasi radikal, laju serta fleksibilitas menjadi suatu hal yang penting.

Mutu pendidikan berkelanjutan pada Suatu lembaga sangat dipengaruhi oleh segenap sumber daya yang ada, serta ditentukan oleh kualitas kepemimpinan dalam mengelola sumber daya di lembaga tersebut. Kepala sekolah dan jajaran kepemimpinan bertanggung jawab dalam mewujudkan mutu yang berkelanjutan. Sehubungan dengan hal ini Sallis menegaskan "...no book can tell an institusion how to achieve total quality for itself - only your customers can tell you that!". (Sallis, 1993 ) Intinya mutu suatu lembaga akan terjamin jika unsur lembaga itu sendiri mampu memenuhi harapan segenap pelanggan (customer). Harapan pelanggan yang dimaksud adalah adanya layanan yang bermutu dan memberikan kepuasan. Upaya ini sangat membutuhkan sistem manajemen yang mampu memberdayakan segenap unsur lembaga melalui kepemimpinan yang efektif.

Dalam rangka mewujudkan program dan mutu pendidikan berkelanjutan pada suatu lembaga pendidikan, seorang pimpinan harus menyadari bahwa "Successful institutions of the future must be as responsive and fluid as the world around them." (Sallis, 1993). Artinya: Institusi (organisasi) yang sukses menuju masa depan adalah institusi yang responsif dan berubah sesuai dengan tuntutan dunia sekitarnya. Dapat dipahami bahwa hal tersebut menuntut kepemimpinan yang inovatif dan mampu menghadapi tantangan perubahan (change).

Ada tiga hal tiga hal penting yang harus diupayakan pemimpin terkait kebutuhan suatu organisasi (lembaga pendidikan) sebagaimana dikemukakan (Sallis, 1993 ) sebagai berikut:

1. Unit optimization (Optimisasi unit): setiap person harus berjalan secara efektif dan efisien berlandaskan standar mutu yang jelas

2. Vertical alignmen (Penjajaran vertikal): setiap person harus memahami strategi, arah dan misi institusi.

3. Horizontal alignment (Penjajaran horizontal): kompetisi antar unit berdasar pada pemahaman terhadap tujuan \& kebutuhan organisasi serta memiliki mekanisme untuk memecahkan masalah.

Berdasarkan konsep di atas dapat dipahami bahwa peran seorang pimpinan lembaga pendidikan sangat menentukan dalam upaya pemenuhan kebutuhan lembaga yang dipimpinnya. Seperti dapat mengupayakan berbagai program dan kegiatan yang relevan 
dengan upaya pemenuhan dan peningkatan serta pengembangan kompetensi pendidik dan tenaga kependidikan di lembaga tersebut sesuai standar yang ditetapkan. Prinsip efektivitas dan efisien, ketepatan strategi, kejelasan arah dan misi yang dipahami segenap unsur lembaga pendidikan, serta kompetisi yang sehat merupakan hal-hal penting yang perlu diupayakan. Hal tersebut dapat menjadi kekuatan dan kunci kesuksesan pimpinan dalam mengemban tugas, fungsi dan tanggung jawabnya memajukan lembaga pendidikan sesuai dengan standar mutu yang dipersyaratkan bagi segenap unsur dan komponen lembaga yang dipimpinnya.

Glenn Cummings telah melakukan penelitian tentang "sustainabilityin higher education" dengan pertanyaan penelitian "what common characteristics and actions were taken by successful university and college leaders in pursuit of sustainability?" (Cummings, 2010) Penelitian dilakukannya di empat perguruan tinggi selama empat tahun. Dua tahun pertama meneliti public research universities dan dua tahun berikutnya meneliti public community colleges. Empat perguruan tersebut adalah: Arizona State University, University of New Hampshire, Cape Cod Community College and Foothill D'Anza Community College District. Kepemimpinan senior di institusi tersebut mengunggapkan watak yang sama dan beberapa strategi yang membuat pemimpinnya mampu mewujudkan sustainability. Ada lima tema yang dimunculkan sebagai berikut: (Cummings, 2010).

Pertama, this research indicates, not surprisingly, that leadership plays a crucial role in the success of sustainability implementation. Artinya bukanlah hal yang asing lagi bahwa peran kepemimpinan merupakan peran yang penting dalam rangka mengimplementasikan sustainability. Hal yang dituntut adalah kemampuan untuk mengembangkan suatu hal yang jelas yaitu sustainability commitment, di mana penghargaan personal merupakan gerakan yang signifikan dalam menghantarkan menjadi institusi yang ideal.

Kedua, the use of administrative policies, particularly human resource management, provided for significant long term impacts in the effort to build sustainability. Yaitu menegaskan bahwa kebijakan administratif, manajemen sumber daya manusia, memberi dampak yang signifikan dalam jangka panjang sehubungan dengan upaya membangun sustainability.

Ketiga, effective leaders used the power of symbolism and "milestones" to underscore the institutional significance of sustainability. Konsisten dengan kerangka kerja "transformational" or "symbolic" selama kepemimpinan merupakan tindakan yang memperkuat jati diri institusi dan mampu menanamkan sustainability sebagai ciri khas lembaga (sekolah). 
Selanjutnya ditegaskan oleh cummings bahwa "...Effective leaders used these opportunities with great skill to promote sustainability." Artinya pemimpin yang efektif mampu menggunakan kesempatan dengan keterampilan besar untuk mewujudkan sustainability. (Cummings, 2010)

Keempat, all four institutions applied both the symbolic and political framework to engage faculty and students. Maksudnya adalah kerangka kerja simbolik dan politis merupakan dua hal yang penting untuk mengarahkan fakultas dan mahasiswa. Kemudian ditegaskan bahwa hubungan moral kepemimpinan dan tanggung jawab merupakan inisiatif penting untuk mewujudkan sustainability.

Kelima, leaders used their ability to "tell the story" of sustainability to engage funders. Maksudnya pemimpin harus mampu transparan dalam hal penggunaan dana.

Akhirnya Cummings menyimpul kan, bahwa pemimpin yang efektif adalah pemimpin yang mampu membangun koalisi dan mampu memaksimalkan pemanfaatan personal dan kekuatan administratif. Integrasi sustainability dalam upaya kepemimpinan memperbaiki kurikulum dapat memberi semangat dan mendorong sustainability dalam menjaga nama baik fakultas. Keterampilan pemimpin menemukan cara untuk mencapai kesuksesan institusi dan menjaga reputasi lembaga. Kemudian kemampuan menggalang dana eksternal (pribadi atau pemerintah) juga merupakan hal yang penting dalam rangka mewujudkan sustainability lembaga. (Cummings, 2010)

D. Komitmen Kepemimpinan dalam Merealisasikan Standar Pendidik dan Tenaga Kependidikan Bagi Pencapaian Mutu Pendidikan

Lestari menyatakan bahwa model sekolah efektif secara kebijakan maupun praktiknya terwadahi dalam program Manajemen Peningkatan Mutu Berbasis Sekolah atau MPMBS. (Lestari, 2011) Pada sekolah efektif, kepala sekolah memiliki peran yang kuat dalam mengkoordinasikan, menggerakkan, dan menyerasikan semua sumber daya pendidikan yang tersedia. Kepemimpinan kepala sekolah merupakan salah satu faktor yang dapat mendorong sekolah untuk dapat mewujudkan visi, misi, tujuan, dan sasaran sekolahnya melalui program-program yang dilaksanakan secara terencana dan bertahap. Oleh karena itu, kepala sekolah dituntut memiliki kemampuan manajemen dan kepemimpinan yang tangguh agar mampu mengambil keputusan dan inisiatif/prakarsa untuk meningkatkan mutu sekolah. Secara umum, kepala sekolah tangguh memiliki kemampuan memobilisasi sumber daya sekolah, terutama sumber daya manusia, untuk mencapai tujuan sekolah.

Untuk merealisasikan sekolah yang efektif dengan mutu pendidikan yang baik membutuhkan suatu komitmen bersama untuk sama-sama memajukan lembaga dan 
meningkatkan kualitas mutu pendidikan. Komitmen segenap unsur lembaga, terutama komitmen tenaga pendidik dan kependidikan khususnya dapat dibangun berawal dari komitmen kepemimpinan yang kuat yang mampu menginspirasi dan memotivasi serta menguatkan segenap unsur dan sumber daya lembaga untuk bersamasama bertekat maju menuju kualitas dan mutu pendidikan yang diharapkan. Dalam hal ini konsep mutu relatif yang dikemukakan Sallis hendaknya dapat menginspirasi pimpinan lembaga pendidikan untuk tidak menyandarkan mutu lembaganya pada segala sesuatu yang mahal. Mutu bisa ditingkatkan berawal dari hal-hal yang kecil dan sederhana, seperti kesungguhan, ketekunan, kegigihan dan kerja sama (teamwork) dalam menjalankan tugas dalam rangka mencapai tujuan yang diharapkan. Sarana dan prasarana yang terbatas hendaknya jangan dijadikan penghalang untuk menjalankan pekerjaan yang berkualitas, karena alat merupakan salah satu bagian kecil saja dari faktor penentu keberhasilan. Tentu dalam hal ini dibutuhkan suatu upaya yang kreatif dan inovatif dari segenap unsur lembaga untuk dapat memberikan layanan pendidikan yang baik sehingga mampu memenuhi segenap standar yang dipersyaratkan bagi tenaga pendidik dan kependidikan khususnya dan standar mutu pendidikan secara umum.

\section{SIMPULAN}

Berdasarkan uraian di atas dapat disimpulkan bahwa banyak hal yang dikuasai dan diperhatikan oleh seorang pemimpin agar dapat menjadi seorang pemimpin yang efektif guna membawa lembaga yang dipimpinnya ke arah yang dicita-citakan sesuai dengan standar yang dipersyaratkan bagi segenap unsur lembaga.

Pemimpin pendidikan yang efektif harus mampu menyadarkan orang yang dipimpinnya terutama pendidik dan tenaga kependidikan, bahwa mutu dan kualitas pendidikan yang baik tidak selalu harus mahal. Dengan kesungguhan, keuletan dan kerja sama (teamwork) yang baik segala tujuan dapat dicapai khususnya standar kualifikasi pendidik dan tenaga kependidikan dapat dipenuhi dan dicapai serta terjaga keberlanjutannya.

Pemimpin pendidikan memiliki tanggung jawab untuk menciptakan kultur organisasi serta iklim yang kondusif bagi upaya meningkatkan pertumbuhan dan mempertinggi pengembangan lembaga pendidikan sesuai dengan standar mutu yang dipersyaratkan. Sehubungan dengan hal ini pemimpin pendidikan memiliki tiga peran utama: bidang kepemimpinan, manajerial, dan pendidik bagi segenap unsur lembaga.

\section{REFERENSI}

Ansyar, M. (2012). Inovasi dan

Implementasi Kurikulum. Lokakarya Penyempurnaan Kurikulum Fakultas Tarbiyah IAIN Imam Bonjol Padang, 10 November 2012 di Bukittinggi.

Bennis, W, \& Nanas, B. (1985). Leaders (The Strategies for taking Charge. New york: New york: Harper \& Row Publishers. 
Cummings, G. (2010). Deputy Assistant Secretary, U.S. Department of Education. The Leadership Factor: Implementing Sustainability in Higher Education. The ACUPCC Implementer.

Hidayati, H. (2015). Kepemimpinan dan peningkatan mutu pendidikan. Jurnal Tarbiyah, 22(1), 48-65. http://dx.doi.org/10.30829/tar.v22i1. 5

Jalal, F., \& Supriadi, D. (2001). Reformasi Pendidikan (Dalam Konteks Otonomi Daerah).

Yogyakarta: Adicita Karya Nusa.

Lestari, S. (2011). Perspektif Kepemimpinan Pendidikan untuk Sekolah Efektif. http://eprints.uny.ac.id/907/2/educati onal_leadership,_slamet_lestari_final

Rivai, V. (2004). Kiat Memimpin dalam Abad ke-21. Jakarta: PT Raja Grafindo Persada. hal. 229-230.

Sa'ud, \& U. (2006). Penjaminan Mutu dalam Peningkatan Mutu Pendidikan tinggi. Bandung: (Hand out Seminar Peningkatan Mutu Pendidikan Tinggi Agama Agama Islam di Lingkungan Departemen Agama). Bandung: Universitas Pendidikan Indonesia.

Sahertian, P. A. (2000). Konsep Dasar dan Teknik Supervis iPendidikan. (Jakarta: Penerbit Rineka Cipta.

Sallis, E. (1993 ). Total Quality Management in Education. London: London: Philadelphia.
Sukmadinata, N. S. (2007). Metode Penelitian Pendidikan. Jakarta: Remaja Rosdakarya.

Wahab, A. (2008). Anatomi Organisasi dan Kepemimpinan Pendidikan. Bandung: Alfabeta. 